\title{
PARTISIPASI APARATUR PEMERINTAH DAERAH KABUPATEN KUNINGAN DALAM KONSERVASI SUMBER DAYA AIR
}

\author{
Suwari Akhmaddhian \\ Fakultas Hukum Universitas Kuningan \\ E-mail : suwariakhmaddhian@gmail.com
}

\begin{abstract}
ABSTRAK. Konservasi sumber daya air memerlukan partisipasi dari masyarakat khusunya aparatur pemerintah sehingga terciptanya lingkungan yang asri dan sehat. Penelitian ini berlokasi di Kabupaten Kuningan Provinsi Jawa Barat. Tujuan penelitian ini adalah untuk mengetahui Pengaturan partisipasi masyarakat dalam konservasi menurut peraturan perundang-undangan di Indonesia dan untuk mengetahui kebijakan pemerintah daerah kabupaten kuningan untuk meningkatkan partisipasi masyarakat dalam konservasi sumber daya air. Metode pendekatan penelitian adalah yuridis empiris dan alat pengumpul data yaitu studi pustaka dan studi lapangan,. Hasil penelitian yaitu: Pertama, Pengaturan partisipasi masyarakat menurut peraturan perundang-undangan di Indonesia, partisipasi masyarakat menurut Undang-Undang Nomor 37 Tahun 2014 Konservasi Tanah dan Air Pasal 2 huruf a yaitu "asas partisipatif". Mengenai rincian bentuk partisipasinya diatur dalam Pasal 46 dan Pasal 52 berisi tentang Peran Masyarakat dan Hak Gugat Masyarakat apabila mengalami kerugian yang diakibatkan oleh kerusakan fungsi tanah dan lahan; Kedua, Kebijakan pemerintah daerah kabupaten kuningan untuk meningkatkan partisipasi masyarakat dalam konservasi sumber daya air, partisipasi masyarakat dalam pelestarian lingkungan hidup di kabupaten Kuningan khususnya Aparatur Peduli Lingkungan adalah kegiatan wajib penanaman pohon oleh aparatur pemerintah daerah kabupaten kuningan yang akan diangkat menjadi pns, kenaikan pangkat, promosi. Aparatur Peduli Lingkungan kegiatan berdasarkan kebijakan pemerintah daerah kabupaten kuningan yaitu Peraturan Daerah Kabupaten Kuningan Nomor 12 Tahun 2007 tentang Konservasi Sumber Daya Air dan Instruksi Bupati Kuningan Nomor 02 Tahun 2011 tentang Pelaksanaan Program Aparatur Peduli Lingkungan Kabupaten Kuningan. Kesimpulan adalah kebijakan pemerintah daerah kabupaten kuningan dalam konservasi sumber daya air sesuai dengan peraturan perundang-undangan dan aparatur pemerintah daerah memberikan contoh kepada masyarakat melalui program aparatur peduli lingkungan.
\end{abstract}

Kata kunci: aparatur peduli lingkungan, kebijakan, konservasi, partisipasi, sumber daya air.

\section{APPARATUS PARTICIPATION OF LOCAL GOVERNMENT DISTRICT KUNINGAN IN WATER RESOURCES CONSERVATION}

ABSTRACT. Water resource conservation needs participation from society so it can create healthy and good environment. This research in Kuningan Regency West Java Province. The objective of this research is to know society participation management based on Indonesian Regulation system and Kuningan Government policies in water conservation. The methods of this research are yuridis empiris. The results of this research are: First, public participation management according to the laws in Indonesia, community participation according to Law Number 37 Year 2014 about Soil and Water Conservation Article 2, 46 and 52 contains the Role of Society and Community Right; the second, Kuningan Government policy in water resource conservation, society participation in environment conservation especially government concerns environment is a mandatory of planting trees by government officer in Kuningan Regency that will be the civil servants, and promotion. The activity relating to this program is based on Kuningan Government policy, Kuningan District Regulation No. 12 of 2007 and Kuningan Regent regulation Number 02 year 2011. The conclusion of thie article is that the Kuningan government policy in water resource conservation is based on the rules and the government officers give good examples to the society in water resource conservation by holding the government concerns environment program.

Key words: government concerns environment, policy, participation, water resource conservation.

\section{PENDAHULUAN}

Pelestarian fungsi lingkungan hidup merupakan tugas bersama antara pemerintah dan masyarakat sehingga terjadi harmonisasi dalam pelaksanaan di lapangan sehingga tujuan kelestarian lingkungan hidup tercapai, partisipasi masyarakat di perlukan dalam mendukung keberhasilan pelestarian lingkungan. Indonesia merupakan Negara Hukum sesuai dengan Pasal 1 ayat (3) Undang Undang Dasar 1945, "Negara Indonesia adalah Negara Hukum”. (Ridwan HR, 2009, 47). Secara konstitisonal terdapat dalam Pasal 28 huruf h ayat 1 (satu) yang berbunyi "setiap orang hidup sejahtera lahir dan batin, bertempat tinggal dan mendapatkan lingkungan hidup yang baik dan sehat serta memperoleh pelayanan kesehatan" dan Pasal 33 ayat (3) yang berbunyi "Bumi dan air dan kekayaan alam yang terkandung di dalamnya dikuasai oleh negara dan dipergunakan untuk sebesarbesar kemakmuran rakyat" pada pasal 28 dikatakan setiap warga negara berhak akan lingkungan yang baik dan sehat, penegakan hukum lingkungan merupakan instrumen untuk menciptakan lingkungan yang baik dan sehat. Undang-undang Nomor 32 Tahun 2009 tentang Perlindungan dan Pengelolaan Lingkungan Hidup menitipberatkan pada perizinan lingkungan sebagai instrumen dalam pengendalian fungsi lingkungan hidup. 
Sedangkan Undang-undang Nomor 37 Tahun 2014 tentang Konservasi Tanah dan Air menitipberatkan pada pemanfaatan tanah dan lahan sebagai instrumen dalam pelestarian fungsi lingkungan hidup. Oleh karena itu peran pemerintah dan partisipasi masyarakat agar terwujudnya pembangunan yang berkelanjutan untuk generasi yang akan datang.

\section{Partisipasi Masyarakat}

Pengertian dan Prinsip Partisipasi Masyarakat Menurut Ach. Wazir Ws (Ach. Wazir Ws et al, 1999, 29) partisipasi bisa diartikan sebagai keterlibatan seseorang secara sadar ke dalam interaksi sosial dalam situasi tertentu. Dengan pengertian itu, seseorang bisa berpartisipasi bila ia menemukan dirinya dengan atau dalam kelompok, melalui berbagai proses berbagi dengan orang lain dalam hal nilai, tradisi, perasaan, kesetiaan, kepatuhan dan tanggungjawab bersama. Partisipasi masyarakat menurut Isbandi (Isbandi Rukminto Adi, 2007, 27) adalah keikutsertaan masyarakat dalam proses pengidentifikasian masalah dan potensi yang ada di masyarakat, pemilihan dan pengambilan keputusan tentang alternatif solusi untuk menangani masalah, pelaksanaan upaya mengatasi masalah, dan keterlibatan masyarakat dalam proses mengevaluasi perubahan yang terjadi. sedangkan menurut Paul B Horton dan C. Hunt (Holil Sulaiman, 1980, 78) masyarakat merupakan kumpulan manusia yang relatif mandiri, hidup bersamasama dalam waktu yang cukup lama, tinggal di suatu wilayah tertentu, mempunyai kebudayaan sama serta melakukan sebagian besar kegiatan di dalam kelompok/ kumpulan manusia tersebut. Masyarakat (yang diterjemahkan dari istilah society) adalah sekelompok orang yang membentuk sebuah sistem semi tertutup atau sebaliknya, dimana kebanyakan interaksi adalah antara individu-individu yang terdapat dalam kelompok tersebut. Kata "masyarakat" berakar dari bahasa Arab, musyarakah. Arti yang lebih luasnya, sebuah masyarakat adalah suatu jaringan hubungan-hubungan antar entitasentitas. Masyarakat adalah sebuah kelompok atau komunitas yang interdependen atau individu yang saling bergantung antara yang satu dengan lainnya. Pada umumnya sebutan masyarakat dipakai untuk mengacu sekelompok individu yang hidup bersama dalam satu komunitas yang teratur. Keberhasilan pembangunan masyarakat desa maka segala program perencanaan, pelaksanaan serta evaluasi pembangunan harus melibatkan masyarakat, karena merekalah yang mengetahui permasalahan dan kebutuhan dalam rangka membangun wilayahnya (Dahyar Daraba, 2017, 53).

\section{Kewenangan dan Kebijakan}

Pemerintahan daerah dalam menyelenggarakan pemerintahannya tidak bisa dilepaskan dari asas legalitas sebagai pijakan dasar dalam membuat peraturanperaturan yang berkaitan dengan kebijakan pemerintahan daerah (Aminuddin Ilmar, 2014, 93). Konsep kebijakan atau dalam bahasa inggris sering kita dengar dengan istilah policy. Dalam Kamus Besar Bahasa Indonesia, kebijakan diartikan sebagai rangkaian konsep dan asas yang menjadi garis besar dan dasar rencana dalam pelaksanaan suatu pekerjaan, kepemimpinan, dan cara bertindak (tentang pemerintahan, organisasi, dsb); pernyataan cita-cita, tujuan, prinsip dan garis pedoman untuk manajemen dalam usaha mencapai sasaran. Carl J Federick sebagaimana dikutip Leo Agustino (Sri Hartini dan Abdul Aziz Nassihudin, 2008, 18-19) mendefinisikan kebijakan sebagai serangkaian tindakan/ kegiatan yang diusulkan seseorang, kelompok atau pemerintah dalam suatu lingkungan tertentu dimana terdapat hambatan-hambatan (kesulitan-kesulitan) dan kesempatan-kesempatan terhadap pelaksanaan usulan kebijaksanaan tersebut dalam rangka mencapai tujuan tertentu. Pendapat ini juga menunjukan bahwa ide kebijakan melibatkan perilaku yang memiliki maksud dan tujuan merupakan bagian yang penting dari definisi kebijakan, karena bagaimanapun kebijakan harus menunjukan apa yang sesungguhnya dikerjakan daripada apa yang diusulkan dalam beberapa kegiatan pada suatu masalah.

Berdasarkan ketentuan Pasal 1 ayat 2 UU No 32 Tahun 2014 tentang Pemerintahan Daerah adalah penyelenggaraan urusan pemerintahan oleh pemerintah daerah dan dewan perwakilan rakyat daerah menurut asas otonomi dan tugas pembantuan dengan prinsip otonomi seluas-luasnya dalam sistem dan prinsip Negara Kesatuan Republik Indonesia sebagaimana dimaksud dalam Undang-Undang Dasar Negara Republik Indonesia Tahun 1945. Melihat definisi pemerintahan daerah seperti yang telah dikemukakan di atas, maka yang dimaksud pemerintahan daerah disini adalah penyelenggaraan daerah otonom oleh pemerintah daerah dan DPRD menurut asas desentralisasi dan unsur penyelenggara pemerintah daerah adalah gubernur, bupati atau walikota dan perangkat daerah. Pemerintah daerah mempunyai kewenangan yang besar untuk merencanakan, merumuskan, melaksanakan, serta mengevaluasi kebijakan dan program pembangunan yang sesuai dengan kebutuhan masyarakat setempat. Sekarang Pemerintah daerah tidak lagi sekedar sebagai pelaksana operasional kebijakan-kebijakan yang telah ditetapkan dan ditentukan oleh pusat, tetapi lebih dari itu diharapkan dapat menjadi agen penggerak pembangunan di tingkat daerah atau lokal (Andi Gajong dan Agus Salim, 2007, 46). Pemerintahan daerah dalam era otonomi darah dan mempunyai kewenangan yang luas khususnya dalam pengelolaan lingkungan hidup maka di perlukan politik hukum yang kuat untuk mewujudkan cita-cita hukum yang amanatkan oleh peraturan perundang-undangan (Deni Bram, 2014, 16).

Wewenang menurut Philipus M. Hadjon sebagai konsep hukum publik sekurang-kurangnya terdiri dari 3 
(tiga) komponen: 1). Pengaruh adalah penggunaan wewenang untuk mengendalikan perilaku subjek hukum; 2). Dasar hukum adalah pengguna wewenang harus bertindak atas dasar peraturan perundang-undangan; 3). Konformitas adalah adanya standar dalam melakukan penggunaan wewenang yaitu standar umum dan standar khusus (Abdul Latif, 2014, 7). Teori Kewenangan terdiri yaitu terdiri dari (Yuslim, 2013, 82-84): 1). Atribusi adalah pemberian wewenang pemerintahan oleh pembuat undang-undang kepada organ pemerintah; 2). Delegasi (delegatie) adalah penyerahan wewenang dari pejabat yang lebih tinggi kepada pejabat yang lebih rendah; 3). Mandat (mandaat) adalah pelimpahan wewenang atau perintah yang diberikan oleh seorang pejabat atas nama jabatannya kepada pihak ketiga untuk melaksanakan sebagian tugas pejabat itu atas jabatan. Tata kelola bisa dilihat dari tujauannya tata kelola atau manajemen pemerintahan dan niaga berbeda, tata kelola pemerintahan tujuanya adalah kesejehteraan masyarakat sedangkan tujuan tata kelola niaga adalah imbalan atau keuntungan ekonomi (Inu Kencana Syafiie, 2014, 118).

Permasalahan utama dalam lingkungan hidup di indonesia yang teridentifikasi ada 5 (lima) antara lain (Nana Sudiana dan Hasmana Soewandita, 2007, 4451): 1) kerusakan lahan akibat penggundulan hutan, penebangan liar, alih fungsi lahan untuk perkebunan dan tanaman industri, penambangan minyak, industri dan permukiman; 2) abrasi pinggir sungai akibat lalulintas pelayaran kapal-kapal besar dan cepat; 3) pendangkalan sungai oleh tingginya erosi, abrasi dan sedimentasi; 4) gangguan pola aliran air permukaan akibat alih fungsi lahan, keberadaan pelabuhan, dermaga, dan logpond; 5) penurunan kualitas air akibat buangan limbah cair industri, domestik pembuangan air ballast kapal, dan buangan limbah padat domestik. Kabupaten Kuningan merupakan daerah pertanian berlokasi di kaki Gunung Ciremai. Kabupaten ini terletak di bagian timur Jawa Barat, berbatasan dengan Kabupaten Cirebon di utara, Kabupaten Brebes (Jawa Tengah) di timur, Kabupaten Ciamis di selatan, serta Kabupaten Majalengka di barat. Kabupaten kuningan pada tahun 2006 telah mendeklarasikan sebagai kabupaten konservasi dan oleh karena itu untuk mewujudkan kuningan sebagai kabupaten konservasi perlu dukungan semua pihak yang terkait, baik pemerintah daerah ataupun masyarakat kabupaten kuningan, untuk menjamin ketersediaan air maka kebijakan pemerintah dalam konservasi perlu didukung melalui bentuk partisipasi semua elemen masyarakat. Aparatur pemerintah sebagai elemen penting dalam penyelenggaraan pemerintahan perlu menjadi pionir dalam mendukung kebijakan pemerintah dalam konservasi sumber daya air.

Masalah lingkungan hidup ini dapat ditinjau dari aspek medik, planologis teknologis, teknik lingkungan, ekonomi dan hukum. Hal ini dikemukakan oleh Siti Sundari Rangkuti yaitu Segi-segi hukum pengelolaan lingkungan hidup dan konservasi sumber daya alam di Indonesia perlu dikaji secara intensif, karena pengelolaan lingkungan tidak mungkin tanpa pengaturan hukum. Hal ini tidak berarti bahwa ahli hukum dapat menangani masalah lingkungan terlepas dari disiplin ilmu lain yang berkaitan dengan bidang lingkungan hidup (Siti Kotijah, 2010, 354-386). Berdasarkan latar belakang tersebut diatas, permasalahan yang akan menjadi fokus perhatian utama yang akan dibahas dalam artikel ini dapat di uraikan diantaranya adalah sebagai berikut: Pertama, bagaimana pengaturan partisipasi masyarakat dalam konservasi sumber daya air menurut peraturan perundang-undangan di Indonesia?; Kedua, Bagaimanakah kebijakan pemerintah daerah kabupaten kuningan untuk meningkatkan partisipasi masyarakat dalam konservasi sumber daya air?

\section{METODE}

Metode penelitian yang digunakan dalam penelitian ini adalah metode deskriptif analisis dan pendekatan yuridis empiris melalui penelitian kepustakaan dan penelitian lapangan. Pengumpulan data dalam penelitian ini berdasarkan data primer yaitu melalui observasi dan wawancara dan data sekunder yaitu Undangundang Nomor 32 Tahun 2009 tentang Perlindungan dan Pengelolaan Lingkungan Hidup, Undang-undang Nomor 37 Tahun 2014 tentang Konservasi Tanah dan Air, Peraturan Daerah Kabupaten Kuningan Nomor 12 Tahun 2007 tentang Konservasi Sumber Daya Air dan Instruksi Bupati Kuningan Nomor 02 Tahun 2011 tentang Pelaksanaan Program Aparatur Peduli Lingkungan Kabupaten Kuningan. Lokasi penelitian di wilayah admistratif kabupaten kuningan provinsi jawa barat. Data yang tersaji dianalisis untuk mengetahui bagaimana kebijakan pemerintah daerah untuk meningkatkan partisipasi masyarakat dalam konservasi sumber daya air.

\section{HASIL DAN PEMBAHASAN}

\section{Pengaturan Partisipasi Masyarakat dalam Kon- servasi Sumber Daya Air}

Lingkungan hidup, dalam bahasa Inggris disebut dengan environment, dalam bahasa Belanda disebut dengan millieu atau dalam bahasa Perancis disebut dengan l'environment. Dalam kamus lingkungan hidup yang disusun Michael Allaby, lingkungan hidup itu diartikan sebagai: the physical, chemical and biotic condition surrounding and organism. Otto Soemarwoto (Koesnadi Hardjasoemantri, 2012, 2), seorang ahli ilmu lingkungan (ekologi) terkemuka mendefinisikannya lingkungan adalah jumlah semua benda dan kondisi yang ada dalam ruang yang kita tempati yang mempengaruhi kehidupan kita. St. Munadjat Danusaputro (Koesnadi Hardjasoemantri, 2012, 41), ahli hukum lingkungan mengartikan lingkungan hidup sebagai semua benda 
dan kondisi, termasuk di dalamnya manusia dan tingkah perbuatannya, yang terdapat dalam ruang tempat manusia berada dan mempengaruhi hidup serta kesejahteraan manusia dan jasad hidup lainnya.

Undang-undang Nomor 32 Tahun 2009 tentang Perlindungan dan Pengelolaan Lingkungan Hidup dalam Pasal 1 ayat 6 memberikan pengertian mengenai pelestarian yaitu "Pelestarian fungsi lingkungan hidup adalah rangkaian upaya untuk memelihara kelangsungan daya dukung dan daya tampung lingkungan hidup". Masyarakat yang merupakan bagian dari lingkungan mempunyai kewajiban dalam melindungi dan memelihara kelangsungan daya dukung dan daya tampung lingkungan hidup.

Menurut Pasal 1 huruf a UU No.32 Tahun 2009 tentang Perlindungan dan Pengelolaan Lingkungan Hidup memberikan pengertian Lingkungan Hidup yaitu "Lingkungan hidup adalah kesatuan ruang dengan semua benda, daya, keadaan, dan makhluk hidup, termasuk manusia dan perilakunya, yang mempengaruhi alam itu sendiri, kelangsungan perikehidupan, dan kesejahteraan manusia serta makhluk hidup lain". Sedangkan pengertian Perlindungan dan pengelolaan lingkungan hidup menurut Pasal 1 huruf a UU No.32 Tahun 2009 Perlindungan dan Pengelolaan Lingkungan Hidup yaitu "Perlindungan dan pengelolaan lingkungan hidup adalah upaya sistematis dan terpadu yang dilakukan untuk melestarikan fungsi lingkungan hidup dan mencegah terjadinya pencemaran dan/atau kerusakan lingkungan hidup yang meliputi perencanaan, pemanfaatan, pengendalian, pemeliharaan, pengawasan, dan penegakan hukum".

Pengaturan partisipasi masyarakat dalam konservasi sumber daya air terdapat di dalam beberapa peraruran perundang-undangan. Asas perlindungan dan pengelolaan lingkungan hidup menurut UU No.32 Tahun 2009 pasal 2 huruf $\mathrm{k}$ yaitu partisipatif dan dalam penjelasan pasal 2 huruf $\mathrm{k}$ yaitu berbunyi "Yang dimaksud dengan "asas partisipatif” adalah bahwa setiap anggota masyarakat didorong untuk berperan aktif dalam proses pengambilan keputusan dan pelaksanaan perlindungan dan pengelolaan lingkungan hidup, baik secara langsung maupun tidak langsung". Berdasarkan Pasal 2 Undang-Undang Nomor 37 Tahun 2014 tentang Konservasi Tanah dan Air Penyelenggaraan Konservasi Tanah dan Air berdasarkan pada asas: a). partisipatif; b). keterpaduan; c). keseimbangan; d). keadilan; e). kemanfaatan; f). kearifan lokal; dan g). kelestarian. Penjelasan Pasal 2 huruf a memberikan penjelasan yaitu " yang dimaksud dengan asas "partisipatif” adalah bahwa setiap anggota masyarakat didorong untuk berperan aktif dalam proses keputusan dan pelaksanaan pelindungan dan pengelolaan Tanah dan Air, baik secara langsung maupun tidak langsung". Undang-undang Nomor 32 Tahun 2009 tentang 2009 tentang Perlindungan dan Pengelolaan Lingkungan Hidup dalam pasal 70 terdapat pengaturan tentang Partisipasi atau Peran Masyarakat dalam perlindungan dan pengelolaan lingkungan hidup dan pengaturan yaitu :

Peran Masyarakat yaitu Pasal 70

1) Masyarakat memiliki hak dan kesempatan yang sama dan seluas-luasnya untuk berperan aktif dalam perlindungan dan pengelolaan lingkungan hidup.

2) Peran masyarakat dapat berupa:

a. pengawasan sosial;

b. pemberian saran, pendapat, usul,keberatan, pengaduan; dan/atau

c. penyampaian informasi dan/atau laporan.

3) Peran masyarakat dilakukan untuk:

a. meningkatkan kepedulian dalam perlindungan dan pengelolaan lingkungan hidup;

b. meningkatkan kemandirian, keberdayaan masyarakat, dan kemitraan;

c. menumbuhkembangkan kemampuan dan kepeloporan masyarakat;

d. menumbuh kembangkan ketanggap segeraan masyarakat untuk melakukan pengawasan sosial; dan

e. mengembangkan dan menjaga budaya dan kearifan lokal dalam rangka pelestarian fungsi lingkungan hidup.

Undang-undang Nomor 32 Tahun 2009 tentang 2009 tentang Perlindungan dan Pengelolaan Lingkungan Hidup dalam Pasal 91 terdapat pengaturan tentang Hak Gugat Masyarakat dalam upaya perlindungan dan pengelolaan lingkungan hidup merasa dirugikan karena adanya pencemaran atau perusakan lingkungan dan pengaturan adalah sebagai berikut:

1) Masyarakat berhak mengajukan gugatan perwakilan kelompok untuk kepentingan dirinya sendiri dan/atau untuk kepentingan masyarakat apabila mengalami kerugian akibat pencemaran dan/atau kerusakan lingkungan hidup.

2) Gugatan dapat diajukan apabila terdapat kesamaan fakta atau peristiwa, dasar hukum, serta jenis tuntutan di antara wakil kelompok dan anggota kelompoknya.

3) Ketentuan mengenai hak gugat masyarakat dilaksanakan sesuai dengan peraturan perundangundangan.

Undang-undang Nomor 37 Tahun 2014 tentang Konservasi Tanah dan Air dalam pasal 46 terdapat pengaturan tentang Partisipasi atau Peran Serta Masyarakat dalam konservasi tanah dan air dan pengaturan adalah sebagai berikut:

1) Masyarakat mempunyai kesempatan yang sama untuk berperan serta dalam penyelenggaraanKoiservasi Tanah dan Air yang dilakukan oleh pemerintah dan/ atau Pemerintah Daerah sesuai dengan kewenangannya.

2) Pelaksanaan peran serta masyarakat dilakukan dengan memperhatikan kearifan lokal. 
3) Peran serta masyarakat dapat dilakukan dalam:
a. penyusunan perencanaan;
b. pendanaan;
c. pengawasan; dan/atau
d. pengajuan gugatan perwakilan/kelompok.

4) Ketentuan lebih lanjut mengenai mekanisme peran serta masyarakat diatur dalam Peraturan pemerintah.

Undang-undang Nomor 37 Tahun 2014 tentang Konservasi Tanah dan Air dalam pasal 52 terdapat pengaturan tentang Hak Gugat Masyarakat apabila mengalami kerugian akibat kerusakan Fungsi Lahan dan Tanah dan pengaturan adalah sebagai berikut:

1) Masyarakat berhak mengajukan gugatan perwakilan kelompok untuk kepentingan diri sendiri dan/atau untuk kepentingan masyarakat apabila mengalami kerugian akibat kerusakan Fungsi Tanah pada Lahan.

2) Gugatan sebagaimana dimaksud pada ayat (1) dapat diajukan apabila terdapat kesamaan fakta atau peristiwa, dasar hukum, serta jenis tuntutan di antara wakil kelompok dan anggota kelompok.

3) Hak gugat masyarakat dilaksanakan sesuai dengan ketentuan peraturan perundang-undangan.

Peraturan Daerah Kabupaten Kuningan Nomor 12 Tahun 2007 tentang Konservasi Sumber Daya Air dalam pasal 35 dan 36 terdapat pengaturan tentang Peran Serta Masyarakat dalam konservasi sumber daya air dan pengaturan adalah sebagai berikut: Pasal 35 yaitu " Masyarakat yang ada dalam dan atau sekitar sumber air dapat diberi prioritas untuk berperan serta dalam kegiatan Konservasi Sumber Daya Air.

Pasal 36 yaitu :

1) Masyarakat mempunyai kesempatan yang sama dan seluas-luasnya untuk berperan dalam pengelolaan lingkungan.

2) Pelaksanaan ketentuan sebagaimana dimaksud pada ayat (1) dilakukan dengan cara :

a. meningkatkan kemandirian, pemberdayaan masyarakat, dan kemitraan;

b. menumbuhkembangkan kemampuan dan kepeloporan masyarakat;

c. menumbuhkan ketanggapsegeraan masyarakat untuk melakukan pengawasan sosial;

d. Memberikan saran pendapat;

e. Menyampaikan informasi dan atau laporan.

Sesuai dengan asas dalam perlindungan dan pengelolaan lingkungan hidup yaitu Partisipasif maka diperlukan peran masyarakat untuk mensuskeskan program-program yang berkaitan dengan upaya pelestarian lingkungan hidup. Partisipasi masyarakat merupakan hal yang sangat diperlukan dalam rangka mendukung kuningan sebagai kabupaten konservasi, Konservasi merupakan hal yang sensitif maka harus melibatkan masyarakat, pengelolaan lingkungan hidup tidak berguna apabila tidak mengikut sertakan masyarakat dan keikutsertaan masyarakat tanpa pengetahuan terhadap esensi pengelolaan lingkungan hidup meyebabkan pemborosan. Jadi, mengikut sertakan masyarakat yang mengerti prinsip kelestarian menjadikan pengelolaan lingkungan hidup efektif dan efisien (Amilur Soeroso, 2007, 49-67). Program-program yang melibatkan partisipasi masyarakat dalam pelestarian konservasi di kabupaten Kuningan adalah sebagai berikut (Suwari Akhmaddhian dan Anthon Fathanudien, 2015, 86-97): Pertama, Seruling yaitu siswa peduli lingkungan; Kedua, Apel yaitu aparatur peduli lingkungan; Ketiga, Pepeling yaitu pengantin peduli lingkungan,; Keempat, Program Car free day atau hari bebas kendaraan bermotor yang dilaksanakan pada hari minggu yang mendapat dukungan dari gubernur jawa barat (Pikiran Rakyat, 2016). Partisipasi masyarakat kabupaten kuningan dalam kebijakan konservasi sumber daya air perlu didukung baik secara kelembagaan maupun peraturan yang perlu ada sebagai dasar hukum dalam melaksanakannya kegiatankegiatan yang bersifat partispasi masayarakat, serta pemerintah daerah mengarahkan pengelolaan air berbasis komunitas sehingga lebih mudah dalam melakukan komunikasi dan koordinasi (Ramadhan Pancasilawan dan Ahmad Buchari, 2014, 165-170).

Pengaturan partisipasi masyarakat dalam pelestarian lingkungan khususnya aparatur pemerintah selain terdapat dalam undang-undang dan peraturan daerah juga Instruksi Bupati Kuningan Nomor 02 Tahun 2011 tentang Pelaksanaan Program Aparatur Peduli Lingkungan Kabupaten Kuningan. Pengaturan ini mensyaratkan kegiatan-kegiatan wajib yaitu penanaman pohon oleh aparatur pemerintah daerah kabupaten kuningan di hutan kota dan kebun raya kuningan yang dalam rangka diangkat menjadi pns, kenaikan pangkat, promosi.

\section{Kebijakan Pemerintah Daerah Kabupaten Kuningan untuk Meningkatkan Partisipasi Masyarakat dalam Konservasi Sumber Daya Air.}

Indonesia merupakan Negara Hukum sesuai dengan Pasal 1 ayat (3) Undang Undang Dasar 1945, "Negara Indonesia adalah Negara Hukum" (Ridwan HR, 2009, 47). Dua belas prinsip pokok sebagai pilar utama yang menyangga berdirinya negara hukum yaitu (Jimly Asshiddiqie, 2016, 98-102): 1). Supermasi hukum; 2). Persamaan dalam hukum; 3). Asas legalitas; 4). Pembatasan kekuasaan; 5). Organ-organ pemerintahan yang independen; 6). Peradilan bebas yang tidak memihak; 7). Peradilan tata usaha negara; 8). Peradilan tata negara; 9). Perlindungan hak asasi manusia; 10). Bersifat demokratis; 11). Berfungsi sebagai sarana mewujudkan tujuan bernegara; dan 12). Transparansi dan kontrol sosial. Secara konstitisonal terdapat dalam Pasal 28 huruf h ayat 1 (satu) yang berbunyi "setiap orang hidup sejahtera lahir dan batin, bertempat tinggal 
dan mendapatkan lingkungan hidup yang baik dan sehat serta memperoleh pelayanan kesehatan" dan Pasal 33 ayat (3) Undang Undang Dasar 1945 yang berbunyi "Bumi dan air dan kekayaan alam yang terkandung di dalamnya dikuasai oleh negara dan dipergunakan untuk sebesar-besar kemakmuran rakyat" pada Pasal 28 Undang Undang Dasar 1945 dikatakan setiap warga negara berhak akan lingkungan yang baik dan sehat, penegakan hukum lingkungan merupakan instrumen untuk menciptakan lingkungan yang baik dan sehat.

Pelestarian alam di Indonesia secara hukum mengacu kepada Undang-Undang Nomor 05 Tahun 1990 tentang Konservasi Sumberdaya Alam Hayati dan Ekosistemnya bertitik berat pada pelestarian keanekaragaman hayati, baik keanekaragaman hayati hutan maupun bukan; baik di dalam kawasan hutan negara maupun di luarnya. Sedangkan Undang-Undang Nomor 41 Tahun 1999 tentang Kehutanan salah satunya mengatur konservasi alam di kawasan hutan negara; namun bukan hanya mencakup konservasi keanekaragaman hayati, melainkan meliputi pula perlindungan fungsifungsi penunjang kehidupan yang disediakan kawasan hutan. Undang-undang Nomor 32 Tahun 2009 tentang Perlindungan dan Pengelolaan Lingkungan Hidup menitiberatkan pada perizinan lingkungan sebagai instrumen dalam pengendalian fungsi lingkungan hidup. Sedangkan Undang-undang Nomor 37 Tahun 2014 tentang Konservasi Tanah dan Air menitiberatkan pada pemanfaatan tanah dan lahan sebagai instrumen dalam pelestarian fungsi lingkungan hidup.

Berdasarkan Pasal 1 ayat 2 Undang-Undang Nomor 37 Tahun 2014 tentang Konservasi Tanah dan Air memberikan pengertian tentang Konservasi Tanah dan Air yaitu "Konservasi Tanah dan Air adalah upaya pelindungan, pemulihan, peningkatan, dan pemeliharaan Fungsi Tanah pada Lahan sesuai dengan kemampuan dan peruntukan Lahan untuk mendukung pembangunan yang berkelanjutan dan kehidupan yang lestari”. Menurut Pasal 1 ayat 18 Undang-Undang Nomor 32 Tahun 2009 tentang Perlindungan dan Pengelolaan Lingkungan Hidup memberikan pengertian Konservasi sumber daya alam yaitu "Konservasi sumber daya alam adalah pengelolaan sumber daya alam untuk menjamin pemanfaatannya secara bijaksana serta kesinambungan ketersediaannya dengan tetap memelihara dan meningkatkan kualitas nilai serta keanekaragamannya". Menurut Pasal 1 ayat 14 Peraturan Daerah Kabupaten Kuningan Nomor 12 Tahun 2007 tentang Konservasi Sumber Daya Air memberikan pengertian "Konservasi sumber daya air adalah upaya memelihara keberadaan serta keberlanjutan keadaan, sifat dan fungsi sumber daya air agar senantiasa tersedia dalam kualitas dan kuantitas yang memadai untuk memenuhi kebutuhan makhluk hidup, baik pada masa kini dan masa depan". Oleh karena itu berdasarkan pengertian konservasi menurut peraturan perundang-undangan maka pelestarian lingkungan hidup erat kaitannya dengan peran pemerintah dan partisipasi masyarakat agar terwujudnya pembangunan yang berkelanjutan untuk generasi yang akan datang.

Roscoe Pound mengemukakan konsep yang disebut "law is tool of social engineering" memberikan dasar yaitu hukum digunakan sebagai sarana perubahan masyarakat, hukum harus berperan aktif dalam merekayasa perubahan sosial dalam masyarakat sehingga hukum harus menjadi faktor penggerak ke arah perubahan masyarakat agar lebih baik daripada sebelumnya (Abdul Manan, 2014, 41-42). Teori Hukum Pembangunan yang dikembangkan Muchtar Kusumaatmaja berdasar dari teori Roscoe Pound memberikan dasar bagi fungsi hukum sebagai Sarana Pembaharuan Masyarakat (Mochtar Kusumaatmaja (Otje Salman dan Eddy Damian), 2013, 3-15). Teori hukum pembangunan pertama kali diwacanakan Mochtar Kusumaatmadja teori itu jauh-jauh hari sudah dimasukkan dalam materi hukum dalam Pelita I (Romli Atmasasmita, 2012, 19).

Menurut I Made Arya Utama, mengemukakan bahwa ada 3 (tiga) hal dasar dalam pengelolaan lingkungan yaitu (Mukhlis dan Mustafa Lutfi, 2010, 29): 1). Kegiatan dalam pengelolaan lingkungan hidup berupa kegiatan adanya kegiatan penataan, kegiatan pemanfaatan, kegiatan pengembangan, kegiatan pemeliharaan, kegiatan pengawasan, kegiatan pengendalian; 2). Pengelolaan lingkungan hidup didasarkan pada prinsip pelestarian "fungsi lingkungan hidup"; 3). Bahwa pengelolaan lingkungan hidup dilakukan melalui pendekatan terpadu dengan adanya penataan ruang maupun perlindungan unsur-unsur lingkungan hidup. Perubahan hukum akan terjadi apabila anggota-anggota masyarakat tidak lagi menjalankan kewajiban-kewajiban yang telah diamanatkan oleh peraturan perundang-undangan yang berlaku di suatu negara (Satjito Raharjo, 2010, 51).

Pemerintahan derah dalam menyelenggarakan pemerintahannya tidak bisa dilepaskan dari asas legalitas sebagai pijakan dasar dalam membuat peraturanperaturan yang berkaitan dengan kebijakan pemerintahan daerah (Aminuddin Ilmar, 2014, 93). Konsep kebijakan atau dalam bahasa inggris sering kita dengar dengan istilah policy. Dalam Kamus Besar Bahasa Indonesia, kebijakan diartikan sebagai rangkaian konsep dan asas yang menjadi garis besar dan dasar rencana dalam pelaksanaan suatu pekerjaan, kepemimpinan, dan cara bertindak (tentang pemerintahan, organisasi, dsb); pernyataan cita-cita, tujuan, prinsip dan garis pedoman untuk manajemen dalam usaha mencapai sasaran. Carl J Federick sebagaimana dikutip Leo Agustino (Sri Hartini dan Abdul Aziz Nassihudin, 2008, 18-19)mendefinisikan kebijakan sebagai serangkaian tindakan/kegiatan yang diusulkan seseorang, kelompok atau pemerintah dalam suatu lingkungan tertentu dimana terdapat hambatanhambatan (kesulitan-kesulitan) dan kesempatan-kesempatan terhadap pelaksanaan usulan kebijaksanaan tersebut dalam rangka mencapai tujuan tertentu. Pendapat 
ini juga menunjukan bahwa ide kebijakan melibatkan perilaku yang memiliki maksud dan tujuan merupakan bagian yang penting dari definisi kebijakan, karena bagaimanapun kebijakan harus menunjukan apa yang sesungguhnya dikerjakan daripada apa yang diusulkan dalam beberapa kegiatan pada suatu masalah.

Undang-undang Nomor 32 Tahun 2009 tentang Perlindungan dan Pengelolaan Lingkungan Hidup dalam pasal 1 ayat 6 memberikan pengertian mengenai pelestarian yaitu "Pelestarian fungsi lingkungan hidup adalah rangkaian upaya untuk memelihara kelangsungan daya dukung dan daya tampung lingkungan hidup". Masyarakat yang merupakan bagian dari lingkungan mempunyai kewajiban dalam melindungi dan memelihara kelangsungan daya dukung dan daya tampung lingkungan hidup. Jadi, mengikutsertakan masyarakat yang mengerti prinsip kelestarian menjadikan pengelolaan lingkungan hidup efektif dan efisien (Amilur Soeroso, 2007, 49-67).

Pemerintah daerah kabupaten Kuningan berdasarkan kewenanganya mengeluarkan kebijakan yaitu berupa perogram Aparatur peduli lingkungan, adalah program yang menyentuh kalangan aparatur pemerintah di kabupaten Kuningan yaitu dengan kegiatan penanaman pohon yang berkaitan dengan kenaikan pangkat serta hari bumi dan hari besar lainnya, dalam program ini setiap pegawai atau aparatur di pemerintah daerah yang pangkatnya naik maka harus menyediakan dan menanam pohon di wilayah yang sudah di tentukan oleh pemerintah daerah tentunya ini merupakan kegiatan yang sangat baik dalam mendukung program pemerintah daerah, berdasarkan Instruksi Bupati Kuningan Nomor 02 Tahun 2011 tentang Pelaksanaan Program Aparatur Peduli Lingkungan Kabupaten Kuningan. Kegiatan Program Aparatur Peduli Lingkungan ini dapat berupa penanaman pohon pada daerah sekitar lingkungan tempat tinggal, penanaman pada lahan-lahan milik pemerintah daerah, seperti : Kebun Raya Kuningan di Desa Padabeunghar Kecamatan Pasawahan; Hutan Kota Bungkirit di Desa Cigugur; dan Hutan kota lainnya. Juga penebaran benih ikan di situ-situ, embung-embung, maupun sungai, serta pelepasan satwa burung dan ikan (Suwari Akhmaddhian, 2013, 446-456).

\section{SIMPULAN}

Pengaturan partisipasi masyarakat Kabupaten Kuningan dalam Konservasi Sumber Daya Air terdapat dalam Konstitusi yaitu Pasal 28 dan Pasal 33 Undang Undang Dasar 1945 dan Undang-undang yaitu Pasal 2, Pasal 70 dan Pasal 91 dalam Undang-undang Nomor 32 Tahun 2009 tentang Perlindungan dan Pengelolaan Lingkungan Hidup dan Pasal 46 dan Pasal 52 dalam Undang-undang Nomor 37 Tahun 2014 tentang Konservasi Tanah serta Pasal 35 dan Pasal 36 Peraturan Daerah Kabupaten Kuningan Nomor 12 Tahun 2007 tentang Konservasi Sumber Daya Air;
Berdasarkan teori kewenangan maka pemerintah daerah Kabupaten Kuningan membuat peraturan untuk mendukung konservasi sumber daya air. Program Aparatur Peduli Lingkungan adalah Kebijakan Pemerintah Daerah dalam Konservasi Sumber Daya Air berdasarkan Peraturan Daerah Nomor 12 Tahun 2007 tentang Konsevasi Sumber Daya Air dan Instruksi Bupati Kuningan Nomor 02 Tahun 2011 tentang Pelaksanaan Program Aparatur Peduli Lingkungan Kabupaten Kuningan. Kegiatan ProgramAparatur Peduli Lingkungan merupakan kebijakan yang dibuat oleh pemerintah darah untuk memberikan contoh kepada masyarakat kabupaten kuningan supaya turut serta menjaga lingkungan.

Berdasarkan simpulan diatas maka saran penulis kepada pemerintah daerah kabupaten kuningan untuk meningkatkan pengetahuan masyarakat tentang konservasi sumber daya airmelalui sosialisasi kepada masyarakat kuningan karena masih ada masyarakat belum tahu akan program-program pelestarian lingkungan yang dilakukan dan dilaksanakan oleh pemerintah daerah sehingga kedepan peran dan partisipasi masyarakat menjadi lebih optimal.

\section{DAFTAR PUSTAKA}

Wazir A.WS. (1999). Panduan Penguatan Menejemen Lembaga Swadaya Masyarakat. Jakarta: Sekretariat Bina Desa dengan dukungan AusAID melalui Indonesia HIV/AIDS and STD Prevention and Care Project, Jakarta.

Akhmaddhian, S. (2013). Peran Pemerintah Daerah dalam Mewujudkan Hutan Konservasi Berdasarkan Undang-Undang No.41 Tahun 1999 Tentang Kehutanan (Studi di Kabupaten Kuningan). Jurnal Dinamika Hukum Vol.13, (3).

Akhmaddhian, S dan Fathanudien, A. (2015). Partisipasi Masyarakat dalam Mewujudkan Kuningan sebagai Kabupaten Konservasi (Studi di Kabupaten Kuningan). Jurnal UNIFIKASI Vol. 2 (1).

Asshiddiqie, J. (2016). Konstitusi Bernegara: Praksis Kenegaraan Bermartabat dan Demokratis, cetakan ke dua, Setara Press, Malang.

Atmasasmita, R. (2012). Teori Hukum Integratif: Rekonstruksi terhadap Teori Hukum Pembangunan dan Teori Hukum Progresif, Genta Publshing, Yogyakarta.

Bram, D. (2014). Politik Hukum Pengelolaan Lingkungan Hidup, Setara Press, Malang.

Daraba, D., (2017). Pengaruh Program Dana Desa Terhadap Tingkat Partisipasi Masyarakat Di Kecamatan Galesong Utara Kabupaten 
Takalar. Sosiohumaniora, Vol. 19 (1).

Gajong, A dan Agussalim. (2007). Pemerintahan Daerah: Kajian Politik dan Hukum, PT. Ghalia Indonesia, Jakarta.

Hardjasoemantri, K. (2012). Hukum Tata Lingkungan Edisi VIII, Gadjah Mada University Press, Yogyakarta.

Hartini, S dan Nassihudin.A.A. (2008). Pengisian Jabatan Sekretaris Desa Di Kabupaten Banyumas (Studi Tentang Kebijakan Pengisian Jabatan Sekretaris Desa), Jurnal Dinamika Hukum, Vol 8 (1)

Aminuddin, I. (2010). Hukum Tata Pemerintahan, Prenada media, Jakarta.

Kotijah, S. (2010). Implementasi Prinsip-prinsip Kehutanan dalam Rangka Konservasi Kehutanan: studi kasus di Jawa Timur, Jurnal Magister Hukum, Vol. 1 (2)

Kusumaatmadja, M., Salman, O. dan Damian, E. (2013). Konsep Konsep Hukum dalam Pembangunan, Alumni, Bandung.

Latif, A. (2014). Hukum Administrasi, Dalam Praktek Tindak Pidana Korupsi, Pranadamedia, Jakarta.

Manan, A. (2014). Peranan Hukum Dalam Pembangunan Ekonomi, Kencana, Jakarta.

Mukhlis dan Mustafa L. (2010). Hukum Adminisrasi Lingkungan Konteporer, Setara Press, Malang.

Pancasilawan, R dan Buchari, A. (2014). Model
Pengelolaan Air Bersih Berbasis Partisipasi Masyarakat di Kawasan Kaki Gunng Manglayang, Sosiohumaniora, Vol.16 (2).

Ridwan, HR. (2009). Hukum Administrasi Negara, FH UII Press, Yogjakarta.

Rukminto, A. dan Isbandi. (2007). Perencanaan Partisipatoris Berbasis Aset Komunitas: dari Pemikiran Menuju Penerapan. Depok: FISIP UI Press, Depok.

Soeroso, A. (2007). Konservasi Lingkungan Kawasan Berbasis Manajemen Pembangunan Masyarakat, Jurnal Ekonomi Pembangunan Vol. 12 (1).

Sudiana, N dan Soewandita, H. (2007). Pola Konservasi Sumber Daya Air di Daerah Aliran Sungai Siak, Jurnal Alami Vol. 12 (1).

Syafiie, I.K. (2014). Sistem Adminsitrasi Negara Republik Indonesia, PT. Bumi Aksara, Jakarta.

Yuslim. (2013). Gagasan Pengaturan Kewenangan Gubernur Sebagai Wakil Pemerintah Setelah Perubahan Undang-Undang Dasar 1945, Jurnal Yustisia, Edisi 86 Mei - Agustus.

http://www.pikiran-rakyat.com/pendidikan /2012/07/16/196153/murid-baru-diharuskanmenyerahkan-bibit-pohon-seruling. diakses pada tanggal 20 Desember 2016 pada jam 20:10 wib. 